\title{
Notes On Accounting Capstone Course Design: Contemporary Issues Versus Case Analysis Enhances Student Interest And Learning
}

Clemense Ehoff, Jr., Kean University, USA

\begin{abstract}
This paper presents how the Internet can be used to bring contemporary issues into the accounting capstone course to enhance student interest and learning. While existing cases have been reviewed and structured, they focus on issues that may not be at the forefront of the items currently under examination and/or debate by the accounting profession. Based on course development and delivery experience at a major Eastern University, the benefits and drawbacks of using the Internet to select contemporary accounting issues are presented and compared to existing research findings as a basis for future study. While the focus of this paper is on accounting capstone courses, the concepts and techniques presented can be applied to capstone courses in other disciplines.
\end{abstract}

Keywords: Capstones courses, Accounting, Internet, Curriculum development

\section{INTRODUCTION}

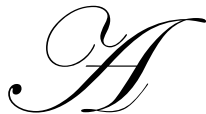

ccounting capstone courses have grown in popularity over the last few years. The concept seems straightforward enough: design a course that challenges the student to solve unstructured problems using knowledge and skills acquired for his entire accounting/business curriculum. Jervis and Huntley (2005) described the concept using the notions of connecting and integrating the curriculum.

The format for accounting capstone courses varies. A brief Internet survey of thirty accounting capstone courses showed the following formats: 1) case course, 2) major research project, 3) accounting theory course, 4) independent study course, 5) auditing course, and 6) contemporary accounting issues. The predominant format was the case course.

The typical case used in a capstone course is rather broad, requires the student to draw from many sources and use multiple techniques in his analysis, and often challenges the student to think critically in an unfamiliar environment. Many of these cases focus on management decision-making, although there has been an increase in the number of cases that focus on accounting reporting issues, such as Deloitte Development LLC (2009). It does not seem unreasonable to think that a case suitable for use in a capstone course would require from six months to a year to develop. Further, it does not seem unreasonable to think that the current list of "hot topics" under consideration by the accounting profession would take even longer to surface in an case suitable for use in an accounting capstone course.

In early 2009, I was given the assignment of teaching an accounting capstone course for a major Eastern University. The course was labeled a contemporary issues accounting course, however, the syllabi that I received from other professors suggested that the course was substantially a case course with a current issue paper. I also learned that the accounting department was reviewing this course for content revisions, so I was given somewhat of a "free hand" for experimentation. Since my colleagues had chosen to focus on the case approach, I chose to 
develop a course that focused primarily on contemporary issues in accounting, relying on the Internet as the source for current events and as the stimulant for student interest. The remainder of this paper describes the results of the experiment.

\section{COURSE STRUCTURE}

Five themes had already been developed for the course: 1) The Role of Contemporary Accounting, 2) Professional Research, 3) Emerging Issues, 4) Professional Auditing, and 5) Consulting. These themes were used as the foundation for the class discussion. We would spend from two to three weeks on each theme. The students and I, as their instructor, would search the Internet for items of interest and bring them to class to share in a discussion. At the end of each theme, students were required to submit a two-page paper summarizing the theme discussion. The short length of the papers was deliberate, as it required students to communicate in writing only the main points of their readings.

Two project assignments were included in the course requirements. The first project was a study of an ongoing Financial Accounting Standards Board (FASB) project, selected from the Technical Plan and Project Update section of the FASB website. A five to seven page paper describing the project and its status was required. The second project was a five to seven page analysis of the Silverado Audio Ltd. (Conway \& Verreault, 2000).

\section{THEME ACTIVITIES}

Gathering contemporary issues for discussion was relatively simple. I entered each theme into an Internet browser and selected approximately fifteen or so articles for class discussion. Students also performed searches and brought their research to the classroom to include in the discussion. Presented below is a brief summary of our discussion for each of the five themes.

\section{The Role of Contemporary Accounting}

After examining the AICPA website, the CPA Vision Project, and other articles obtained from the Internet search, the class identified five key factors that have significantly altered accounting's place in the business world. First, the role that accounting plays in business has expanded dramatically. The internal accountant has become a much stronger voice in upper management, and the external accountant has become a management consultant. Second, there has been an "explosion" of standards and rules put forth by the accounting profession and regulatory bodies. Third, the collapse of Enron, WorldCom, Adelphia, and others, along with the demise of Arthur Andersen (once thought impossible) have severely damaged the reputation of the accounting profession. Fourth, the supply of new accountants has been eroding since the passage of the 150-hour education requirement. Finally, the CPA profession needs to develop a strategy to restore public confidence in their work.

\section{Professional Research}

The 2008/2009 collapse of the real estate market sparked an enormous amount of controversy around FASB 157 and 159, commonly referred to as the mark-to-market rules. During the first few months of 2009, numerous articles surfaced each day in newspapers, journals, and the Internet. Mortgage News Clips (MNC), for example, posted an eight-article piece on March 14, 2009 (Pearson). Student interest in this particular subject was enormous.

After reading the FASB Statements and reviewing Internet pieces supporting and criticizing the mark-tomarket controversy, the students concluded that the mark-to-market controversy had yet to be resolved. Their sticking point was similar to the one raised by many business professionals: efficient markets had all but disappeared, making fair value judgments near impossible. 


\section{Emerging Issues}

There is no better place to find emerging issues than the FASB's Emerging Issues Task Force webpage. On October 16, 2008, the FASB issued a discussion paper, requesting comments on a proposed reformatting of financial statements (FASB). The proposed financial statements bore little resemblance to the financial statements currently in use. Instead, the proposed statements followed a structure similar to the existing cash flow statement. Indeed, the proposed statements were viewed as a radical departure from the existing financial statement structure. The proposed income statement, for example, presented comprehensive income. The proposed balance sheet presented cash in the financing section. The students concluded that financial statements, as they knew them, would likely change in the future, probably not as much as the what they has just seen.

\section{Professional Auditing}

The Internet is loaded with professional auditing issues. What peaked the interest of our discussion was a 2002 article which noted that auditing firms gave unqualified opinions to $42 \%$ of the public companies that later filed for bankruptcy during the first half of 2002 (Weiss). This article raised two major issues for further scrutiny. The first issue centered on the going concern assumption and how far into the future an auditor should consider its relevance, given that an audit is reporting on historical data. The second issue concerned bankruptcy. The students wondered if auditors should present bankruptcy indicator statistics as supplemental information. Some students believed that maybe the audit profession was being unfairly held responsible for the decisions of management.

\section{Consulting}

In this discussion, the class focused on the future of the accounting profession. The CPA Vision project became the main focus of our discussion (CPA Vision). Two conclusions emerged from our discussion. First, future growth will likely come from consulting services (such as forensics and elder care) and other attest functions (such as ISO 9000 engagements), not from auditing and tax preparation as it has been in the past. Second, the seemingly never-ending "logjam" of new rules and regulations will hasten specialization of accounting firms; the "one stop" accounting firm appears to be headed for extinction.

\section{BENEFITS AND DRAWBACKS}

In just a few short years, the Internet has become the primary current events source for many professionals and casual users. It has become a virtual library, stocked with a seemingly endless package of current events from nearly every source imaginable. It has become the tool of choice for obtaining current events news in nearly every professional discipline.

This paper has shown that using the Internet to bring contemporary issues into an accounting capstone course is not only viable, but an ideal approach. The websites of AICPA and the FASB offer numerous current events issue for discussion and analysis. Simply entering a topic into a browser is likely to produce a substantial array of topics suitable for an accounting capstone course.

At the end of the course, I asked for student comments regarding the approach used for this course. Most students responded favorably to what they called a "sobering" view of the accounting profession that they would soon join. With respect to the case assignment, some students reacted favorably, while others suggest that the case resembled a CPA exam simulation. Some of these students had to wait at least another year before they were able to take the exam. For those students, the case assignment was viewed as somewhat meaningless.

The most significant drawback in using the Internet for bringing contemporary issues into the accounting capstone course is the amount of instructor time needed to construct the course. Clearly, the time involved in gathering data, reviewing it, and organizing it for a meaningful class discussion far outweighs the time necessary to construct a case course. 


\section{CONCLUSION}

As senior accounting students prepare to enter the business environment as accounting professionals, the accounting capstone course is an ideal forum for initial exposure to contemporary issues that the accounting profession must resolve. The Internet eases the task of compiling contemporary accounting issues and remaining current. A similar approach could be employed in capstone courses for other disciplines.

This experiment has shown the worthiness of incorporating contemporary issues in an accounting capstone course. It is hoped that this experiment will stimulate others to consider including a contemporary issues component in their accounting capstone courses.

\section{AUTHOR INFORMATION}

Dr. Clemense Ehoff Jr., CPA is Assistant Professor of Accounting, Kean University, Union New Jersey. He holds a Ph. D in Business Administration from San Francisco's Golden Gate University. He has more than 30 years professional business experience and has held full-time faculty and adjunct positions at universities predominantly in the Eastern United States. Over the last ten years, Dr. Ehoff has been involved in teaching accounting and tax courses in an online platform. He operates a consulting and tax practice. He has published articles in Elevator World, and other journals.

\section{REFERENCES}

1. American Institute of Certified Public Accountants (AICPA) (2000) The CPA Vision Project 2011 and Beyond. Retrieved January 31, 2009 from http://www.cpavision.org/vision.htm.

2. Conway, G. M. \& Verreault, D.A. (2000) Silverado Audio, LTD. Analysis of Investment Opportunity in a Start-up Company. The American Institute of Certified Public Accountants (AICPA). Case No. 2000-10, 113.

3. Deloitte Development, LLC. (2009). Retrieved August 25, 2009 from http://www.deloitte.com/view/en_US/us/Services/audit-enterprise-risk-services/Financial-StatementInternal-Control-Audit/Accounting-StandardsCommunications/article/7692899a961fb110VgnVCM100000ba42f00aRCRD.htm.

4. $\quad$ Financial Accounting Standards Board (FASB) Discussion Paper: Preliminary Views on Financial Statement Presentation. Retrieved August 25, 2009 from http://www.fasb.org/DP_Financial_Statement_Presentation.pdf.

5. Jervis, K. J., \& Hartley, C. A. (2005, November) Learning to Design and Teach an Accounting Capstone. Issues in Accounting Education, Vol. 20, No. 4, 311-339.

6. Pearson, C. (2006-2007). MNC Special: Mark to Market Controversy - 8 Articles. Retrieved on February 15, 2009 from http://mortgagenewsclips.com/2009/03/14/mnc-special-mark-to-market-controversy-8articles/.

7. Weiss, M. D. (July 5, 2002). The Worsening Crisis of Confidence on wall Street. Retrieved April 13, 2009 from http://www.weissratings.com/worsening_crisis.asp. 